\title{
A CASE OF FOREIGN BODY (A LARGE FRAGMENT OF PLATE-GLASS) IN THE NASAL SEPTUM
}

\author{
By \\ T. OGURA AND I. OWADA

\section{From the Department of Oto-Rhino-Laryngology, Faculty of Medicine, University of Tokyo (Director: I. Kirikae)}

\begin{abstract}
A twenty-nine-year-old female visited our clinic with chief complaints of slight nasal obstruction and crust formation in both nasal cavities.

Anterior rhinoscopy at that time revealed a foreign body covered with darkish crust in the median portion of the nasal septum, resembling a tumor in its appearence.

A fragment of plate-glass, $1.6 \mathrm{~cm}$ in width, $5 \mathrm{~cm}$ in length and $0.3 \mathrm{~cm}$ in depth, was removed by an endonasal operation,

This fragment was considered to have stuck in the nasal septum through a trauma three months before.
\end{abstract}

\section{鼻中隔に茨入停在した異物症例

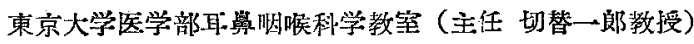

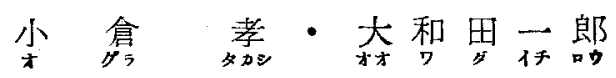

比較的大きな碃子片が，外儩により右鼻翼の尖端部を 穿通して鼻中澏に熊入停在し，3ケ月後に摘出された症 例を程験したので報告する。

\section{臨 床 所 見}

\section{症例：29才：和}

\section{家族歴，既往歷火特記するものなし．}

現症：昭和 33 年 4 月 23 日，自宅の瑯下で，誤つて 頭から硝子戸に激突した。その時，硝子の棒状破片を右 鼻翼に突き刺し，直ちに自分でこの破片を拔きとり外科 医を訪れたが，買出血多量のため㤔近の専門医に紿介さ れた：その時つ所見は，右鼻翼の尖端部に，硝子の刺入 部と思われる裂傷か認められ，鼻腔内には，とりあえず ガーゼダンポンが施されてあつた・また大量の止血刱の 注射も受けていた。鼾出血はとの後む容易に止まらず， 数日後に完全に止血したとのことである．以後鼻腔内の 清㳦により経過を観察していたところ，鼻中隔の穿孔が 明らか沉り，さらに腐骨形成の氮いも生じてきたとの ことで，外傷後 86 日目に東大耳鼻咽呢科外来に紹介さ
れて来院した。

来院時主訴：㹢皮形成（悪臭はない）軽度の鼻閉塞. 全身所見：顔貌正常, 体格や上大, 栄盖良好, 血液 所見正常.

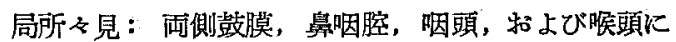
特別の所見はない、線像にも，明らかな骨欠損，また は異物と思われる陰影㳊認められない。顔面の腫脹，外 鼻の畸型はなく，右鼻翼の尖端部に約 $1 \mathrm{~cm}$ の線状の般 痕が諗められる。

鼻鏡所見では，第 1 図の如く両側の中鼻道は，ほ心゙正 常であるが，鼻䶼粘腾は一般に軽度に発赤腫脹し，右鼻 腔の下训介前端部の内側面からぼ゙鼻中隔の中央部にか けて，特よび左鼻腔の下甲介中央部门内側面に，黑褐色 の瘀皮があり，一見腫場を思わせる所見であつた・右鼠 腔の湤皮に稪われた部方をを消息子で探ると，硬い抵抗が あり，痂皮の一部を除去すると青黑色に輝く部分が見ら れた・試みに右鼻腔より，この部分を鉬子で毫引する と，反対側鼻腔の 痂皮も同時に 動くのが認められたの で、アナムネーゼから鼻中區中央部を穿通して両則鼻腔 

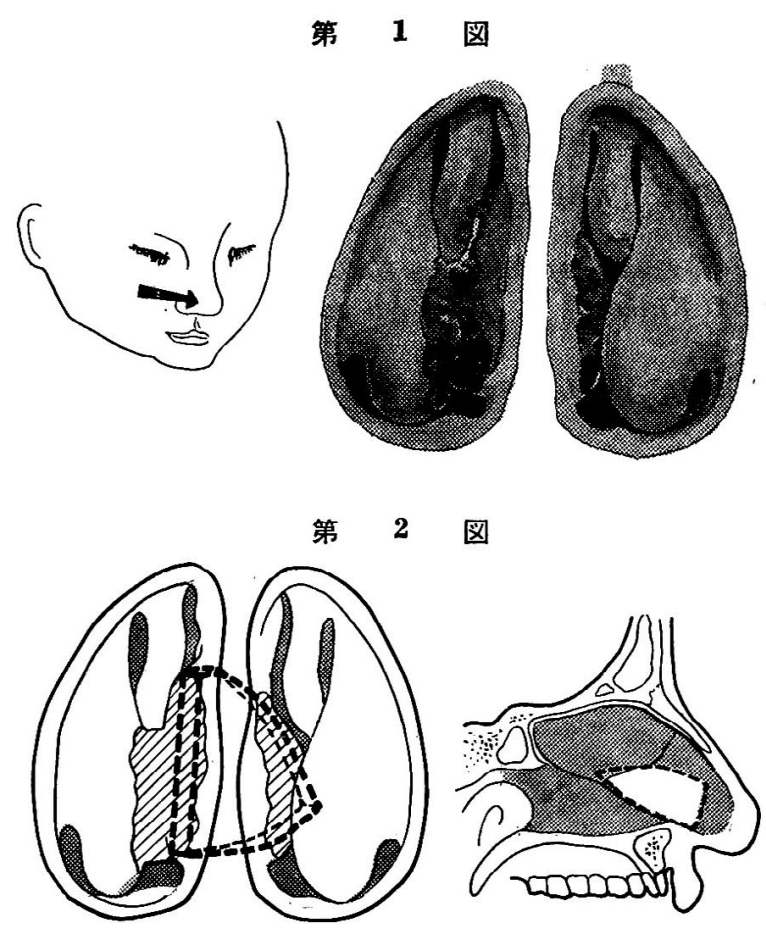

图
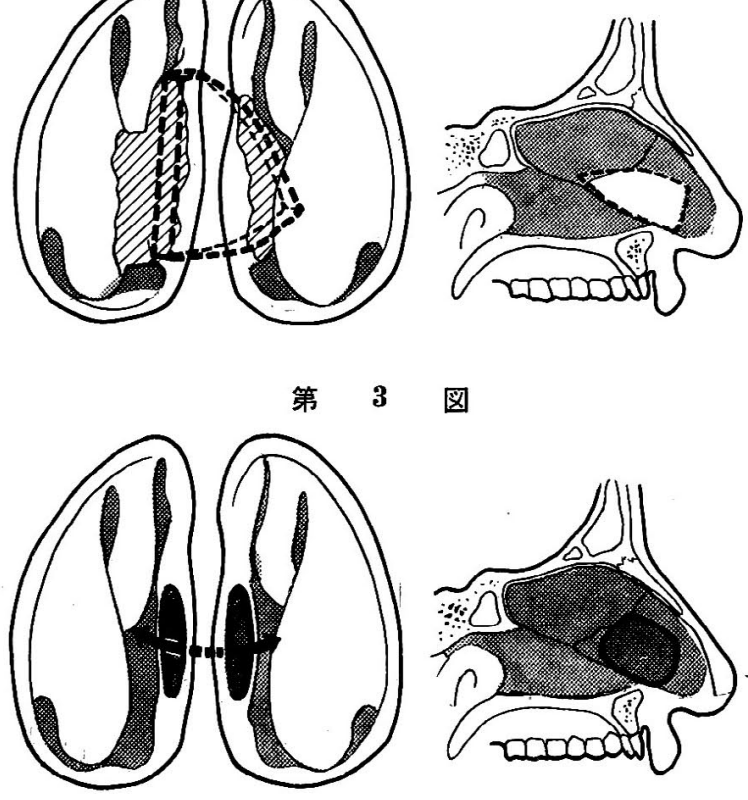

図

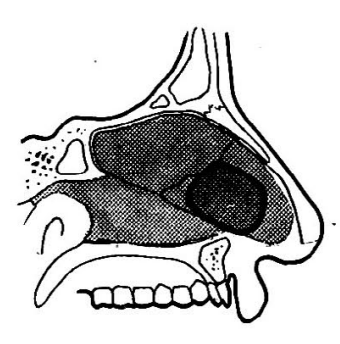

にまたがる硝子片が存在するのであろうと侤えられた (第2 図).

\section{手 術 所見}

局所麻酔のもとに，鼻中隔中央部の前端に，異物嵌入 部に沿うて上下に切開を施し, 周用に剝離を加えると暴 物の動摇が見られ，釷子にて容易に摘出することができ た・すなわち，異物は鼻中隔軟骨部を右前端部から後端 部にかけて第 2 図の如く，斜めに穿通していたものであ る.術中術後の出血は，少量であつた・摘出後，鼻中际 中央部の軟骨部に底辺約 $2 \mathrm{~cm}$, 高さ約 $1.6 \mathrm{~cm}$ の汪ら゙楕 円形の穿孔が認められた（第3図）.
摘 出 異 物

摘出異物は第 4 図の如く, 尖端刀揳状にとがうた 厚さ $3 \mathrm{~mm}$ の硝子片で, 大ささは $4.9 \mathrm{~cm} \times 1.6 \mathrm{~cm}$ である・

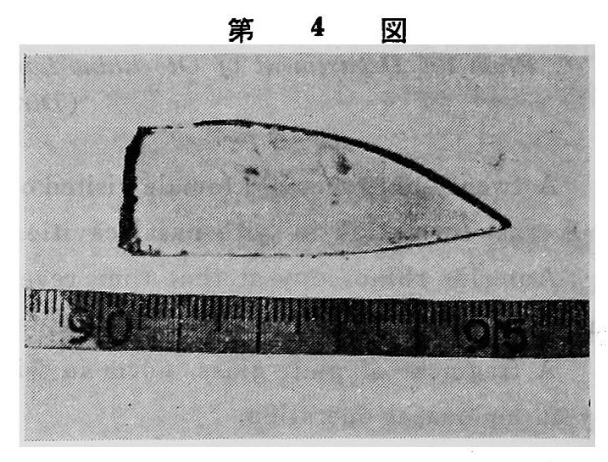

\section{䱜中隔穿孔部の処置}

鼻中隔穿孔部の大きさは, 底辺 $2 \mathrm{~cm}$, 高さ $1.6 \mathrm{~cm}$ に特よぶ情円形で，軟骨部に限局している・そ

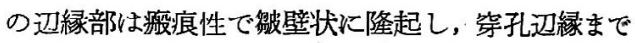
骨，軟骨が存在している.

先づ, Yankauer, Halle の法に従つて，左鼻中 隔粘膜に, 鼻春に近く後上方に向う弧状の減張切閉 を施しこれを剝離して穿孔部を閉塞しよらと試み た・しかしながら穿孔部はあまりにも大きくて、そ の下端まで覆らことは不可能であつた・このため第 2 の試みとして，反対側の鼻腔底粘膜を下鼻道附近 より穿孔部に向つて剥離し, 両側の粘膜弁を重ね合 わせようと試みたが，これでも穿孔部全面を覆らこ とは不可能で，一部小穿孔を残したま〉縫合した。 3 ケ月後には，この小穿孔は再び㹡がり, 術前の大 きさにほざ近い程度になつた・しかて患者自身の自 覚症状は殆んどなくなつた。

\section{文献的考察}

我国に括ける外傷による鼻腔異物をしらべてみると， 第 1 表の如くである.

この表をみると，異物の種類で最も多いのは，空気銃 弾の 4 例である.これはいられわ子供が迶戯中に誴射さ れたもので，異物の膟留期間は外傷即日から7.日であ る・その他，作業中に飛来した木片，鉄片，遊戲中に爆 発した機関砲弾执よび不滤の事故による自動車の空気調 節挺の破片，小石，硝子片等である・この中で木片およ び空気調節挺の破片以外の 4 例は，異物の滞留期間が 1 カ月から長いものは7年に就よんでいる.そして2例 
第 1 表外鹪性秉胵暴物

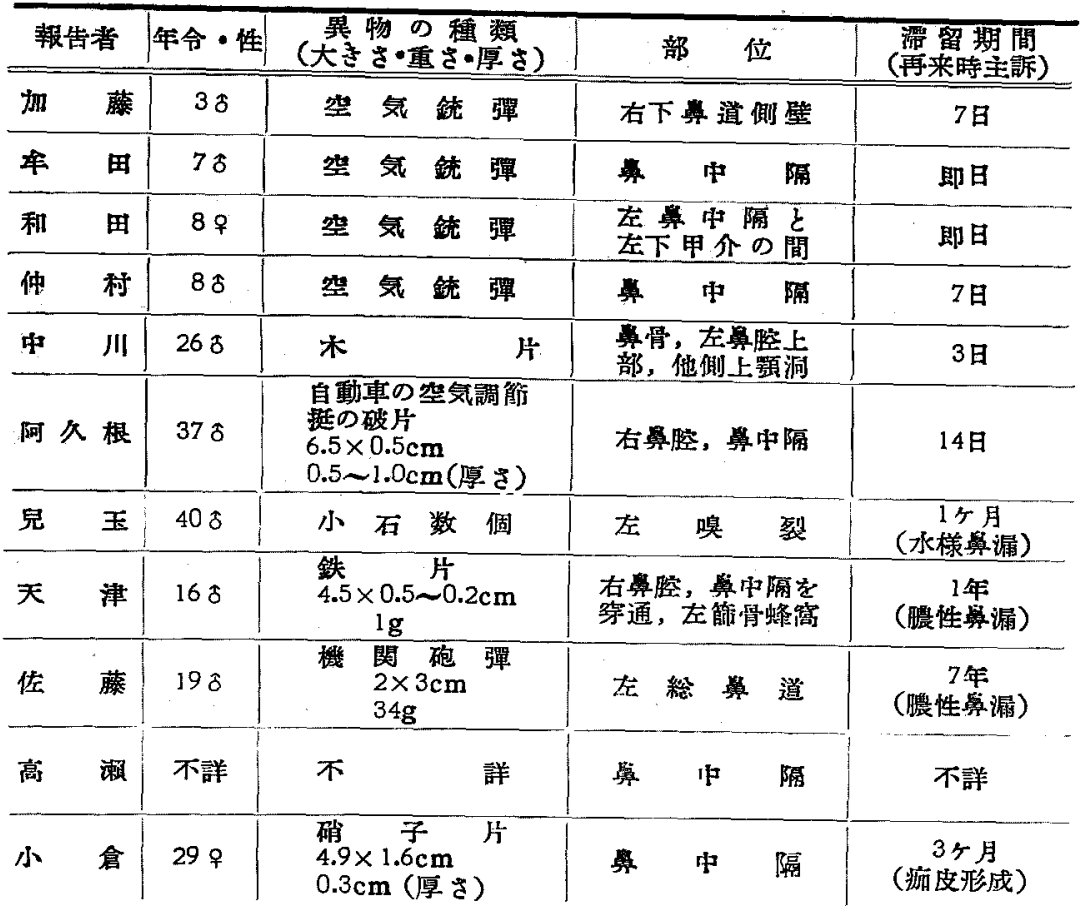

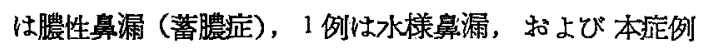
は㿂皮形成の主訴で再度専門医の治療を受け，先の原因 が，異物停在のためと判明し，摘出にょり全治した例で ある。

\section{むすび}

外傷により，異物が 鼻中隔にのみ嵌入停在した 報告 は，比較的稀である（第 1 表参照，11例のらち4例に みられる)・

本症例は，尖端が楔状にとがつた厚さ $3 \mathrm{~mm}, 4.9 \mathrm{~cm}$ $\times 1.6 \mathrm{~cm}$ の大きな碚子片が，鼻中隔に 3 ケ月間滞留して いたすのである・その刺入経路は，右鼻翼尖端部を穿通 し，鼻中隔軟骨部に前端部より後端部にかけて斜めに嵌 入し、鐁骨，笠骨正中板の抵抗をうけて鼻中隔中央部に 停止したものと思われる。

\section{荅 文 献}

1) 阿久根陵：日本耳㚜咽喉科会武，50:637. 2) 天

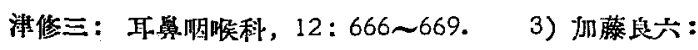

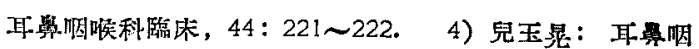
喉科，8：1016 1019. 5) 部田理：日本耳悬㖞喉科 会辡，58：363.6）仲利信夫：日本耳悬咽喉科会報， $53:$ 104.7) 和川一郎：日本耳男呐喉科会裉，51：

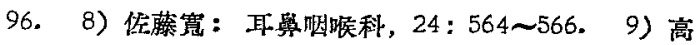

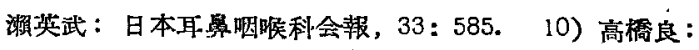
日本耳尊咽唉科全書，第 2 卷，第 4 册，102１10. 11)

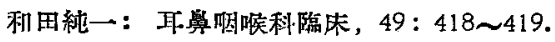

擱筆するにあたり切替一郎教变の御校閵並びに高 城千尋博士，佐藤靖雄助教授の御坛方々御好意心装 心より感謝する。

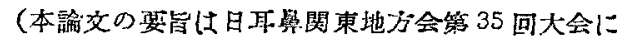
おいて発表した)。

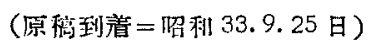

